\title{
Commentary: Moving the goalposts in arch replacement
}

\author{
Abe DeAnda, Jr, MD
}

\footnotetext{
From the Division of Cardiovascular and Thoracic Surgery, University of Texas Medical Branch-Galveston, Galveston, Tex.

Disclosures: Author has nothing to disclose with regard to commercial support.

Received for publication Feb 16, 2019; accepted for publication Feb 18, 2019; available ahead of print March 20, 2019.

Address for reprints: Abe DeAnda, Jr, MD, Division of Cardiothoracic Surgery, UTMB-Galveston, 301 University Blvd, Galveston, TX 77551 (E-mail: abdeanda@utmb.edu).

J Thorac Cardiovasc Surg 2020;159:46-83

$0022-5223 / \$ 36.00$

Copyright $\Subset 2019$ by The American Association for Thoracic Surgery

https://doi.org/10.1016/j.jtcvs.2019.02.072
}

The traditional surgical approaches to the distal aortic arch and proximal descending thoracic aorta were the choice between the single-stage arch-first approach ${ }^{1}$ and a 2 -stage procedure. With the latter, the second-stage procedure was fraught with difficulty and complications, and it often required a period of circulatory arrest. Improvements came with the introduction of the elephant trunk procedure, which created a free extension of prosthetic graft into the distal aorta, thereby eliminating the proximal suture line in the second stage and making the subsequent procedure easier. ${ }^{2}$ Thirty-years after describing this procedure, Hans Borst ${ }^{3}$ reflected on the number of modifications and simplifications of his original technique and remarked, "There probably is no method that cannot be improved."

Improved it was. Svensson ${ }^{4}$ invaginated the graft to make the distal anastomosis easier to perform. A modification by Suto and colleagues ${ }^{5}$ described the use of a distal stent in conjunction with an elephant trunk, paving the way to the current frozen elephant trunk approach. ${ }^{6}$ Taniguchi and associates ${ }^{7}$ described a modified conventional elephant trunk technique for both aneurysmal disease and dissections, with the proximal extent being at the take-off of the innominate artery. Their approach involved a long trunk and was associated with $4 \%$ incidence of paraplegia or paraparesis.

In this issue of the Journal, Yamamoto and colleagues ${ }^{8}$ present a variation on the theme, combining the proximal extent described by Taniguchi and associates ${ }^{7}$ with the frozen elephant trunk technique in their approach to type A dissections. As with the traditional frozen elephant trunk for dissections, obliteration of the proximal false lumen ideally will lead to favorable aortic remodeling downstream. Circulatory arrest with selective cerebral perfusion is still required, as are exposure, dissection, and mobilization of the arch vessels. The technical benefits of this approach are the elimination for extensive arch resection and the avoidance of performing the distal determined.

\section{References} 2013;145:44. 1992; 7:301-12.

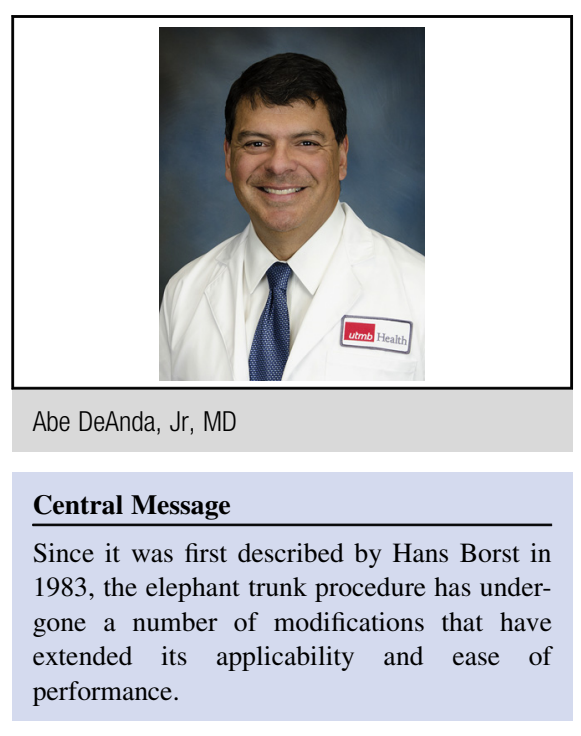

See Article page 36.

anastomosis in what can sometimes be a deep hole. Although an experienced aortic surgeon can usually secure the distal suture confidently, bleeding from this suture line can be problematic and difficult to address. This concern is lessened by moving the suture line farther proximally. In addition, mobilization of the neurovascular structures traversing the arch near the distal suture line, that is, the phrenic and vagus nerves, is no longer necessary. Interestingly and promisingly, the incidence of spinal cord injury was $0 \%$ in these patients. Whether this is a reflection of the modified technique remains to be

Evolution of techniques should be the rule and not the exception in our profession. Borst's observation ${ }^{3}$ remains as cogent today as it was when he wrote it in 2013.

1. Kouchoukos NT, Masetti P, Rokkas CK, Murphy SF. Single-stage reoperative repair of chronic type A aortic dissection using the arch-first technique. Ann Thorac Surg. 2002;74:S1800-2; discussion S1825-32.

2. Borst HG, Walterbusch G, Schaps D. Extensive aortic replacement using "elephant trunk" prosthesis. J Thorac Cardiovasc Surg. 1983;31:37-40.

3. Borst HH. The birth of the elephant trunk technique. J Thorac Cardiovasc Surg.

4. Svensson LG. Rationale and technique for replacement of the ascending aorta, arch, and distal aorta using a modified elephant trunk procedure. J Card Surg.

5. Suto Y, Yasuda K, Shiiya N, Murashita T, Kawasaki M, Imamura M, et al. Stented elephant trunk procedure for an extensive aneurysm involving distal 
aortic arch and descending aorta. J Thorac Cardiovasc Surg. 1996;112: 1389-90.

6. Karck M, Chavan A, Khaladj N, Friedrich H, Hagl C, Haverich A. The frozen elephant trunk technique for the treatment of extensive thoracic aneurysms: operative results and follow-up. Eur J Cardiothorac Surg. 2005;28:286-90; discussion 290 .
7. Taniguchi K, Toda K, Hata H, Shudo Y, Matsue H, Takahashi T, et al. Elephant trunk anastomosis proximal to origin of innominate artery in total arch replacement. Ann Thorac Surg. 2007;84:1729-34.

8. Yamamoto H, Kadohama T, Yamaura G, Tanaka F, Takagi D, Kiryu K, et al. Total arch repair with frozen elephant trunk using the "zone-0 arch repair" strategy for type A acute aortic dissection. J Thorac Cardiovasc Surg. 2020;159:36-45.

Access to The Journal of Thoracic and Cardiovascular Surgery Online is reserved for print subscribers!

Full-text access to The Journal of Thoracic and Cardiovascular Surgery Online is available for all print subscribers. To activate your individual online subscription, please visit The Journal of Thoracic and Cardiovascular Surgery Online, point your browser to http://www.mosby.com/itcvs, follow the prompts to activate your online access, and follow the instructions. To activate your account, you will need your subscriber account number, which you can find on your mailing label (note: the number of digits in your subscriber account number varies from 6 to 10). See the example below in which the subscriber account number has been circled:

\section{Sample mailing label}

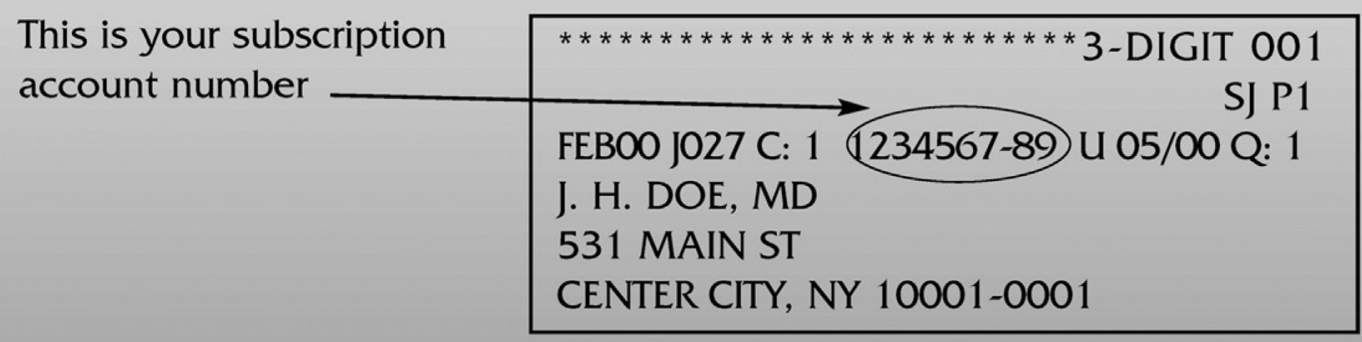

Personal subscriptions to The Journal of Thoracic and Cardiovascular Surgery Online are for individual use only and may not be transferred. Use of The Journal of Thoracic and Cardiovascular Surgery Online is subject to agreement to the terms and conditions as indicated online. 